\section{Nitrogen Rate and Timing of Nitrogen Application in Poinsettia (Euphorbia pulcherrima Willd. Ex Klotz.)}

\author{
Mary Ann Rose ${ }^{1}$ \\ Department of Horticulture, Ohio State University, 2001 Fyffe Court, Columbus, \\ $\mathrm{OH} 43210$
}

\author{
John W. White ${ }^{2}$ \\ Department of Horticulture, The Pennsylvania State University, University \\ Park, PA 16802
}

Additional index words. subirrigation, nutrition, saturated medium extract, tissue analysis, Kjeldahl N

\begin{abstract}
Celebrate 2' Poinsettias were grown for 8 weeks in a controlled-environment growth room until first signs of bract coloration. In growth stage I (GSI; weeks 1 through 4) low, medium, and high $\mathrm{N}$ rates $(25,75$, and $125 \mathrm{mg} \mathrm{N} /$ liter, respectively) were applied by subirrigation (no leaching). Following floral induction [growth stage II (GSII), weeks 5 to 8], there were nine treatments: all possible combinations of the three $\mathbf{N}$ rates in GSI plus three rates $(75,125$, and $175 \mathrm{mg}$ N/liter) in GSII. Although $>80 \%$ of shoot dry weight and $>90 \%$ of total leaf area developed during growth GSII, reaching an acceptable plant size by week 8 depended on receiving adequate fertilization in growth GSI. In contrast, leaf chlorosis, noted in plants receiving the lowest rate in GSI, was rapidly reversed by increasing the $\mathbf{N}$ rate in GSII. Quadratic regression equations fitted to shoot dry weight and leaf area data predicted that using $125 \mathrm{mg} \mathrm{N} / \mathrm{liter}$ in both growth stages gave maximum responses at week 8 . However, using $75 \mathrm{mg} \mathrm{N} / \mathrm{liter}$ in GSI and $125 \mathrm{mg}$ N/liter in GSII also produced acceptable growth in poinsettias. Our results suggest that some growth restriction imposed by $\mathrm{N}$ availability during the first 4 weeks of growth may be acceptable and perhaps desirable to reduce growth regulator use and the environmental impact of overfertilization.
\end{abstract}

Growers are frequently advised to fertilize container crops early and heavily after potting, when root growth is critical. Although $\mathrm{N}$ in the root zone may increase root density, high $\mathrm{N}$ concentrations in the growing medium early in growth may depress root elongation and promote unfavorable root : shoot ratios [Klemm, 1966 (cited by Marschner, 1986)]. Typical poinsettia fertilizer recommendations assume leaching and suggest using 300 to 400 $\mathrm{mg} \mathrm{N} / \mathrm{liter}$ for the first few irrigations after potting, then reducing the application rate to 250 or $300 \mathrm{mg} \mathrm{N} /$ liter (Ecke et al., 1990). Using high $\mathrm{N}$ rates at potting is thought to achieve optimum fertility levels in the growing medium. However, there have been few studies to support the practice, and few studies determine what is optimum at specified stages of growth. Furthermore, fertilizer recommendations should distinguish between irrigation

Received for publication 25 Oct. 1993. Accepted for publication 27 May 1994. This paper is a portion of a thesis submitted to the graduate school of The Pennsylvania State Univ., University Park, by M.A.R. in partial fulfillment of a $\mathrm{PhD}$ degree. We thank Paul Ecke Ranch for supplying the plants used in this experiment. The cost of publishing this paper was defrayed in part by the payment of page charges. Under postal regulations, this paper therefore must be hereby marked advertisement solely to indicate this fact.

${ }^{1}$ Assistant Professor.

${ }^{2}$ Professor Emeritus. methods because application rates may be substantially reduced when leaching is eliminated (Biernbaum et al., 1988).

In support of the fertilize-early-and-heavily practice, Tolman et al. (1990) suggested that young marigold plants (Tagetes patula L.) may require higher $\mathrm{N}$ concentrations than mature plants because smaller root systems acquired a smaller proportion of total $\mathrm{N}$ from nutrient solutions. Higher uptake rates in young plants, however, may compensate for smaller root systems. King and Stimart (1990) found that chrysanthemums [Dendranthema grandiflorum (Ramat.) Kitamura] had higher $\mathrm{N}$ uptake per unit dry weight in the first 4 weeks of growth than in later growth stages. Furthermore, high-N application rates after potting may decrease growth. After 3 and 8 weeks of growth, poinsettias supplied with $400 \mathrm{mg}$ N/liter had significantly lower root and shoot dry weights than plants supplied with $\mathrm{N}$ rates that increased from 0 to 400 $\mathrm{mg} \cdot$ liter $^{-1}$ over 5 weeks (top and subirrigation used; Argo and Biernbaum, 1991).
Our preliminary work suggests that marketable poinsettias could be grown with 125 $\mathrm{mgN} /$ liter constantly supplied by subirrigation. In this study, we focused on the $\mathrm{N}$ requirement of 'Celebrate 2' poinsettia in the first two stages of growth that occur in a typical production cycle. The first growth stage (GSI; the early vegetative stage) encompasses the first 4 weeks of growth, from potting to the beginning of the inductive photoperiod. We have observed rapid root growth during this stage, but relatively slower shoot growth (unpublished). The second 4-week growth stage (GSII; the inductive stage) includes floral induction and is a period of rapid leaf growth and stem elongation. Our objective was to characterize the $\mathrm{N}$ requirement of poinsettia in the two growth stages and to determine how $\mathrm{N}$ rate in the GSI affects growth later in development. We wanted to minimize the $\mathrm{N}$ applied in poinsettia production while maintaining desirable crop quality. Although the $\mathrm{N}$ requirement in the third and final poinsettia development stage was not examined, other authors have demonstrated that $\mathrm{N}$ application rates may be reduced during bract development (Nell and Barrett, 1986; Senecal et al., 1989).

\section{Materials and Methods}

Culture. Rooted cuttings of 'Celebrate 2' were potted 26 Feb. 1992 in 1250-ml pots containing 2 peat : 1 perlite : 1 vermiculite medium (by volume). The growing medium was amended (in $\mathrm{kg} \cdot \mathrm{m}^{-3}$ ) with 0.6 superphosphate, 1.2 dolomitic lime, 3.0 calcitic lime, and 0.9 trace elements (Micromax Micro nutrients; Grace-Sierra, Fogelsville, Pa.). Plants were pinched to six nodes on 11 Mar. following the first harvest.

Environment. Growth room day/night temperatures were $24.0 \pm 0.7 \mathrm{C}$ and $19.1 \pm 0.7 \mathrm{C}$ throughout the experiment. Fluorescent lighting provided $340 \mu \mathrm{mol} \cdot \mathrm{m}^{-2} \cdot \mathrm{s}^{-1}$ at canopy level. Daylength was $14 \mathrm{~h}$ before floral induction and $10 \mathrm{~h}$ thereafter.

Treatments. In GSI or the early vegetative stage of growth, three $\mathrm{N}$ rates were applied (in $\mathrm{mg} \mathrm{N} /$ liter): $\mathrm{LO}=25, \mathrm{ME}=75$, and $\mathrm{HI}=125$. In GSII or the inductive stage (weeks 5 through 8 ), each rate was increased by $50 \mathrm{mg} \mathrm{N} / \mathrm{liter}$ (in $\mathrm{mg} \mathrm{N} / \mathrm{liter}$ ): $\mathrm{LO}=75, \mathrm{ME}=125$, and $\mathrm{HI}=175$ $\mathrm{mg}$ N/liter. Although there were only three treatments in GSI, in GSII there were nine: all possible combinations of $\mathrm{LO}, \mathrm{ME}$, or $\mathrm{HI}$ rates in each of the two growth stages (Table 1). Each nutrient solution supplied (in mg.liter ${ }^{-1}$ ) variable $\mathrm{N}, 40 \mathrm{P}, 98 \mathrm{~K}, 120 \mathrm{Ca}, 20 \mathrm{Mg}, 57 \mathrm{~S}$, and 0.5 Mo from $\mathrm{NH}_{4} \mathrm{NO}_{3}, \mathrm{H}_{3} \mathrm{PO}_{4}, \mathrm{~K}_{2} \mathrm{SO}_{4}$, $\mathrm{Ca}\left(\mathrm{NO}_{3}\right)_{2} \cdot 4 \mathrm{H}_{2} \mathrm{O}, \mathrm{CaCl}_{2} \cdot 2 \mathrm{H}_{2} \mathrm{O}, \mathrm{MgSO}_{4} \cdot 7 \mathrm{H}_{2} \mathrm{O}$, and $\left(\mathrm{NH}_{4}\right)_{6} \mathrm{Mo}_{7} \mathrm{O}_{24} \cdot 4 \mathrm{H}_{2} \mathrm{O}$. The $\mathrm{NO}_{3}: \mathrm{NH}_{4}$ ratio

\begin{tabular}{|c|c|c|c|}
\hline \multicolumn{4}{|c|}{ Main factor } \\
\hline $\mathrm{N}$ rate used & $\mathrm{N}$ rate used & getative stage (gl & SSI) $\left(\mathrm{mg} \cdot\right.$ liter $\left.^{-1}\right)$ \\
\hline in GSII (mg.liter $\left.{ }^{-1}\right)$ & LO (25) & ME (75) & HI (125) \\
\hline $\mathrm{LO}(75)$ & 25-75 (LL) & 75-75 (ML) & 125-75 (HL) \\
\hline ME (125) & $25-125(\mathrm{LM})$ & $75-125(\mathrm{MM})$ & $125-125(\mathrm{HM})$ \\
\hline HI (175) & $25-175(\mathrm{LH})$ & $75-175(\mathrm{MH})$ & $125-175(\mathrm{HH})$ \\
\hline
\end{tabular}


Soll Management, Fertilization, \& Irrigation

was 9:1 and 4:1 in the first 4 and last 4 weeks of growth, respectively. Only the $\mathrm{N}$ and $\mathrm{Cl}$ concentrations varied among treatments $(\mathrm{Cl}=$ 166,82 , and 0 and 124,62 , and $0 \mathrm{mg} \cdot \mathrm{liter}^{-1}$ for LO, ME, and HI in GSI and GSII, respectively). Drip tubes supplying individual saucers subirrigated each plant as determined by the grower (about every 2 to 3 days). No leaching occurred; all applied solution was absorbed by the medium. The total $\mathrm{N}$ applied was calculated from the volume and concentration of applied fertilizer solutions.

Harvest procedures. Poinsettias were harvested at 2-week intervals for 8 weeks; at each harvest, plant height, diameter, and leaf area of four plants per treatment were measured. After lateral growth development (harvests 3 and 4), two leaf area measurements were madenew leaves on lateral shoots and basal leaves on the primary stem. The numbers and lengths of the lateral shoots also were measured. Whole shoots were analyzed for total $\mathrm{N}$ by a Kjeldahl method (Bremner, 1965). No pretreatment was used with the Kjeldahl procedure because, in related experiments, shoot $\mathrm{NO}_{3}-\mathrm{N}$ concentrations were low $(0.1 \%$ to $0.2 \%)$ in poinsettias supplied with $250 \mathrm{mg}$ N/liter.

Medium analysis. The growing medium in each pot was sectioned equally into top, middle, and bottom layers; each layer was analyzed for $\mathrm{pH}, \mathrm{NO}_{3}-\mathrm{N}$ concentration, and electrical conductivity (EC) using the saturated medium extract procedure (Warncke, 1988).

Statistical analysis. SAS statistical procedures were used for analysis of variance and regression (SAS Institute, Cary, N.C.). The three treatments in GSI were analyzed as a simple randomized complete-block design (RCBD). In GSII, the nine treatments were analyzed as a RCBD with a factorial arrangement of treatments. Four replications of treatments were arranged on four benches in the growth room.

Growth analysis. Average shoot N-accumulation rates per unit dry weight $\left(\mathrm{NAR}_{\mathrm{dw}}\right.$, milligrams shoot $\mathrm{N}$ per gram shoot dry weight per week) were calculated for 2-week intervals using interval formulas described by Hunt (1990),

average $\mathrm{NAR}_{\mathrm{dw}}=\left(\mathrm{N}_{2}-\mathrm{N}_{1}\right)\left(\mathrm{t}_{2}-\mathrm{t}_{1}\right) \times\left(\ln \mathrm{W}_{2}\right.$ $\left.-\ln \mathrm{W}_{1}\right) /\left(\mathrm{W}_{2}-\mathrm{W}_{1}\right)$

where $\mathrm{N}=$ shoot $\mathrm{N}$ content (milligrams), $\mathrm{W}=$ shoot dry weight (grams), $\mathrm{t}=$ week after potting.

\section{Results}

Qualitative observations of growth and appearance. Within 2 weeks of potting, $\mathrm{N}$ deficiency symptoms were visible in the LO rate treatment in GSI; at 4 weeks, retarded lateral shoot development also was evident in this group. Plants receiving ME or $\mathrm{HI}$ rates were similar in appearance and acceptable in quality at 4 weeks. At 6 weeks, the treatments receiving the LO rate in GSI had lost most of the basal leaves that originated from stock plants; however, at final harvest (8 weeks), the loss of the basal leaves did not have much
Table 2. Effect of $\mathrm{N}$ rate in growth stage I.

\begin{tabular}{|c|c|c|c|c|}
\hline $\mathrm{N}$ rate $^{z}$ & $\begin{array}{c}\text { Total shoot } \\
\mathrm{N} \text { content }(\mathrm{mg})\end{array}$ & $\begin{array}{c}\text { Shoot N } \\
\text { concn }(\%)\end{array}$ & $\begin{array}{c}\text { Shoot } \\
\text { dry wt (g) }\end{array}$ & $\begin{array}{c}\text { Shoot } \\
\text { length }(\mathrm{cm})\end{array}$ \\
\hline \multicolumn{5}{|c|}{ Treatment means, simple randomized complete-block design analysis at week 4} \\
\hline LO & 45 & 2.3 & 1.9 & 1.6 \\
\hline ME & 94 & 3.4 & 2.8 & 2.2 \\
\hline HI & 95 & 4.2 & 2.3 & 2.4 \\
\hline Maximum $^{y}$ & 117 & --- & --- & 112 \\
\hline $\mathrm{N}$ rate & $\mathrm{L}^{* *}, \mathrm{Q}^{\mathrm{x}}$ & $\mathrm{L}^{* * *}$ & NS & $L^{* *}, Q^{x}$ \\
\hline$r^{2}$ & 0.89 & 0.96 & 0.58 & 0.83 \\
\hline $\mathrm{SE}^{\mathrm{w}}$ & 12.8 & 0.2 & 0.4 & 0.2 \\
\hline
\end{tabular}

${ }^{2} \mathrm{~N}$ rates (in mg.liter ${ }^{-1}$ ): $\mathrm{LO}=25, \mathrm{ME}=75$, and $\mathrm{HI}=125$.

${ }^{y}$ Maximum $=$ the $\mathrm{N}$ rate that gave the maximum response in the dependent variable where quadratic model was used.

${ }^{x}$ Significant at $P \leq 0.10$. Using quadratic fit justified if sum of squares for quadratic effect exceeded $5 \%$ of total sum of squares.

${ }^{w_{S E}}$ of the difference between two treatment means.

Ns, ${ }^{* *}, * * *$ Nonsignificant or significant at $P \leq 0.01$ or 0.001 , respectively. $\mathrm{L}=$ linear, $\mathrm{Q}=$ quadratic.

Table 3. Effect of $\mathrm{N}$ rate in growth stage II (GSII).

\begin{tabular}{|c|c|c|c|c|}
\hline \multirow[b]{3}{*}{$\underline{\mathrm{Nrate}^{\mathrm{z}}}$} & \multicolumn{2}{|c|}{$\begin{array}{c}\text { Total shoot } \\
\mathrm{N} \text { content }(\mathrm{mg})\end{array}$} & \multicolumn{2}{|c|}{$\begin{array}{c}\text { Shoot N } \\
\text { concn }(\%)\end{array}$} \\
\hline & \multicolumn{2}{|c|}{ Weeks after potting } & \multicolumn{2}{|c|}{ Weeks after potting } \\
\hline & 6 & 8 & 6 & 8 \\
\hline \multicolumn{5}{|c|}{ Main effect means, factorial analysis } \\
\hline \multicolumn{5}{|c|}{ Growth stage I (GSI) } \\
\hline LO & 84 & 212 & 3.9 & 4.3 \\
\hline ME & 157 & 308 & 4.1 & 3.9 \\
\hline $\mathrm{HI}$ & 174 & 346 & 4.0 & 3.9 \\
\hline Maximum $^{y}$ & 115 & --- & --- & --- \\
\hline \multicolumn{5}{|l|}{ GSII } \\
\hline LO & 133 & 225 & 3.9 & 3.5 \\
\hline ME & 131 & 312 & 4.1 & 4.1 \\
\hline $\mathrm{HI}$ & 152 & 328 & 4.1 & 4.4 \\
\hline Maximum & --- & --- & --- & --- \\
\hline GSI rate & $\mathrm{L}^{* * * *}, \mathrm{Q}^{* *}$ & Interaction & NS & $\mathrm{L}^{* * * *}, \mathrm{Q}^{* *}$ \\
\hline GSII rate & NS & Interaction & NS & $\mathrm{L}^{* * * *}$ \\
\hline GSI $\times$ GSII & NS & * & NS & NS \\
\hline$r^{2}$ & 0.83 & 0.90 & 0.22 & 0.89 \\
\hline $\mathrm{SE}^{\mathrm{x}}$ & 9.3 & 12.4 & 0.2 & 0.1 \\
\hline
\end{tabular}

${ }^{2}$ GSI N rates (in mg.liter ${ }^{-1}$ ): $\mathrm{LO}=25, \mathrm{ME}=75$, and $\mathrm{HI}=125$; $\mathrm{GSII} \mathrm{N}$ rates: $\mathrm{LO}=75, \mathrm{ME}=125$, and $\mathrm{HI}=$ 175.

${ }^{\mathrm{y}}$ Maximum $=$ the $\mathrm{N}$ rate that gave the maximum response in the dependent variable where quadratic model was used.

${ }^{\mathrm{x}_{\mathrm{SE}}}$ of the difference between two main effect means.

Ns, ${ }^{* * *, * * * *}$ Nonsignificant or significant at $P \leq 0.05,0.01$, or 0.001 , respectively. $\mathrm{L}=$ linear, $\mathrm{Q}=$ quadratic.

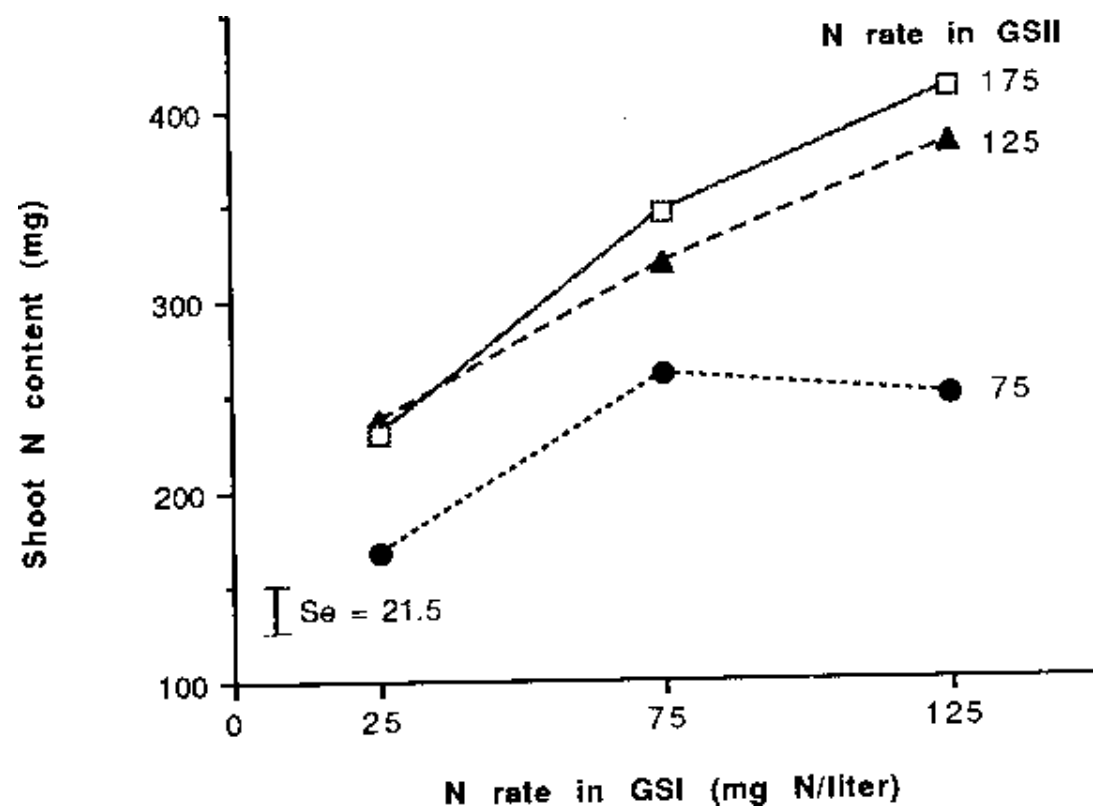

Fig. 1. Nitrogen contents of whole shoots at week 8. SE bar indicates SE of the difference between two treatment means. 
impact on appearance because these five or six leaves were a small fraction of total leaf area. At 8 weeks, plants receiving the LO rate in GSI were noticeably smaller than those in other treatments, but the new shoot growth was no longer chlorotic. It seems that the increase in the $\mathrm{N}$ rate applied in all treatments $(+50 \mathrm{mg} \mathrm{N} /$ liter) at week 5 was enough to improve the appearance of these plants. Plants that received any combination of ME or HI rates were visually inseparable at final harvest and had satisfactory growth and quality. At final harvest, plants of all treatments showed initial signs of bract coloration.

Growth measurements during GSI. At weeks 2 and 4, regression analyses indicated that $\mathrm{N}$ rate had significant linear and quadratic effects on $\mathrm{N}$ content and shoot length (only week 4 data shown) (Table 2). Quadratic functions fitted to the data at week 4 predicted that maximum responses of shoot length and $\mathrm{N}$ content occurred at application rates close to the HI rate, 112 and $117 \mathrm{mg} \mathrm{N} / \mathrm{liter}$, respectively. In GSI, shoot dry weight, basal leaf area, plant diameter, plant height, and the number of side branches were not affected by the $\mathrm{N}$ rates. Although shoot lengths were affected by $\mathrm{N}$ rate, plant heights were not because they reflected shoot elongation less precisely .

Effect of $N$ rate used in GSI on growth measurements in GSII. The N rate used in GSI had a significant effect on shoot $\mathrm{N}$ content at week 6 (Table 3 ) and week 8 (Table 3 and Fig. 1), which was independent of the effect of $\mathrm{N}$ rate used in GSII. Quadratic functions fitted to data from week 6 predicted a maximum response in $\mathrm{N}$ content (115 mg N/liter) close to the HI rate used in GSI. Despite the GSI $\times$ GSII interaction at week 8 (Table 3); graphical representation of the data (Fig. 1) indicated that, with the exception of the HI-LO treatment, $\mathrm{N}$ content increased with increasing $\mathrm{N}$ rate used in GSI.

More than $80 \%$ of shoot dry weight and $>90 \%$ of total leaf area were added in GSII. Nonetheless, the $\mathrm{N}$ rate used in GSI had a critical effect on growth in GSII. Regardless of the $\mathrm{N}$ rate received in GSII, plants that received the LO rate in the GSI had much lower dry weights and smaller leaf areas when all treatment combinations were considered (Fig. 2). At final harvest (week 8), GSI N rate had significant linear and quadratic effects on shoot dry weight, new shoot area, and basal leaf areas (Table 4). Quadratic functions predicted that maximum responses of shoot dry weight and new shoot leaf area occurred at 127 and $114 \mathrm{mg} \mathrm{N} /$ liter, respectively, close to the HI GSI rate, but the maximum response of basal leaf area was not achieved by the $\mathrm{HI}$ rate. Basal leaves originated from mother plants, and in contrast to other growth characteristics where $\mathrm{N}$ promoted growth, $\mathrm{N}$ prevented senescence of the older, basal leaves in later growth stages. Basal leaves are sensitive indicators of $\mathrm{N}$ status because $\mathrm{N}$ deficiency promotes rapid mobilization of $\mathrm{N}$ from old to new leaves (Marschner, 1986). Shoot lengths at week 6 were significantly increased by increasing $\mathrm{N}$ rate (GSI), but no significant trends were observed at week 8 (data not shown).

Effects of $N$ rate used in GSII on growth measurements in GSII. The effect of $\mathrm{N}$ rate used in GSII on N content was not significant at week 6 (Table 3 ), but by week 8 , the effect

Table 4. Effect of $\mathrm{N}$ rate on shoot growth measurements at final harvest (week 8).

\begin{tabular}{lccc}
\hline \hline $\begin{array}{l}\text { N rate } \\
\left(\mathrm{mg} \cdot \text { liter }^{-1}\right)\end{array}$ & $\begin{array}{c}\text { Shoot } \\
\text { dry wt }(\mathrm{g})\end{array}$ & $\begin{array}{c}\text { New shoot leaf } \\
\text { area }\left(\mathrm{cm}^{2}\right)\end{array}$ & $\begin{array}{c}\text { Basal leaf area } \\
\left(\mathrm{cm}^{2}\right)\end{array}$ \\
\hline GSI rate & \multicolumn{2}{c}{ Main effects means, factorial analysis } \\
LO & 4.9 & 1063 & \\
ME & 7.9 & 1353 & 65 \\
HI & 8.8 & 1418 & 239 \\
Maximum & 127 & 114 & 319 \\
GSII rate & & & 142 \\
LO & 6.4 & 1172 & 206 \\
ME & 7.7 & 1347 & 216 \\
HI & 7.5 & 1316 & 208 \\
Maximum & 140 & 138 & --- \\
GSI & $\mathrm{L}^{* * * *}, \mathrm{Q}^{* * *}$ & $\mathrm{~L}^{* * *}, \mathrm{Q}^{*}$ & $\mathrm{~L}^{* * *}, \mathrm{Q}^{*}$ \\
GSII & $\mathrm{L}^{* * *}, \mathrm{Q}^{*}$ & $\mathrm{~L}^{*}, \mathrm{Q}^{\mathrm{w}}$ & $\mathrm{NS}$ \\
GSI $\times$ GSII & $\mathrm{NS}$ & $\mathrm{NS}$ & $\mathrm{NS}$ \\
$r^{2}$ & 0.86 & 0.68 & 0.88 \\
SE $^{v}$ & 0.4 & 69 & 20
\end{tabular}

${ }^{2} \mathrm{GSI}=$ growth stage I with $\mathrm{N}$ rates (in $\mathrm{mg} \cdot \mathrm{liter}^{-1}$ ): $\mathrm{LO}=25, \mathrm{ME}=75$, and $\mathrm{HI}=125$.

${ }^{y}$ Maximum $=$ the $\mathrm{N}$ rate that gave the maximum response in the dependent variable, where quadratic model was used.

${ }^{\mathrm{x}} \mathrm{GSII}=$ growth stage II with $\mathrm{N}$ rates $\left(\right.$ in $\left.\mathrm{mg} \cdot \mathrm{liter}^{-1}\right): \mathrm{LO}=75, \mathrm{ME}=125$, and $\mathrm{HI}=175$.

wSignificant at $P \leq 0.10$. Use of quadratic fit justified at the 0.10 level if sum of squares for quadratic effect exceeded $5 \%$ of total sum of squares.

${ }^{{ }} \mathrm{SE}$ of the difference between two main effect means.

Ns, *,**,****Nonsignificant or significant at $P \leq 0.05,0.01$, or 0.001 , respectively. $\mathrm{L}=$ linear, $\mathrm{Q}=$ quadratic.
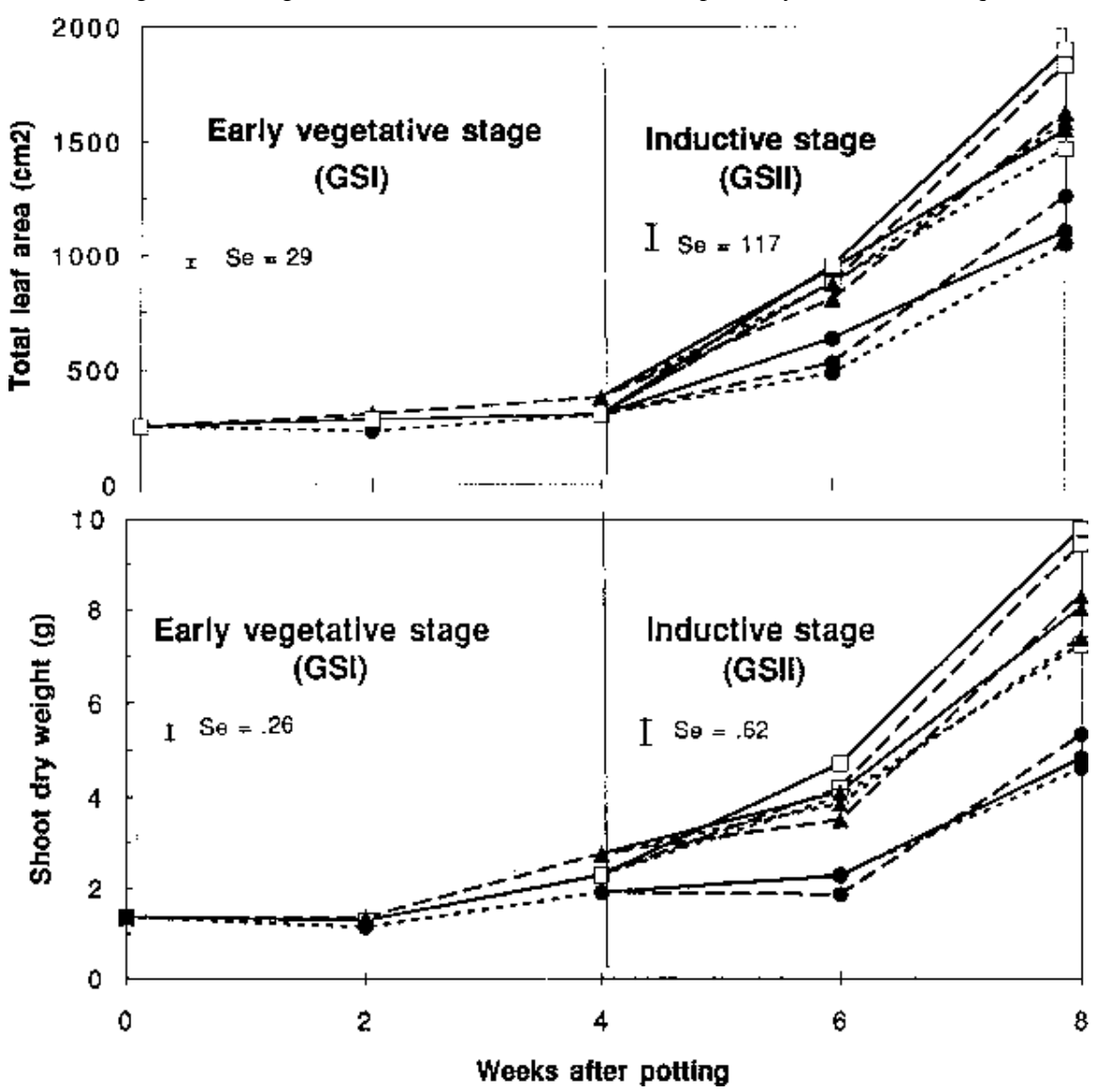

Fig. 2. Total leaf area (upper graph) and shoot dry weight (lower graph) of the three treatments in GSI and nine treatments in GSII. Treatment key (in mg N/liter): HH 125-175 ( $\square-\square$ ), HM 125-125 (-- $\square--$ ), HL 125-75 (- - - - ), MH 75-175 (- $\boldsymbol{\Delta}-$ ), MM 75-125 (-- $\boldsymbol{\Delta}--)$, ML 75-75 (--- $\mathbf{\Delta - - - ) , ~ L H ~ 2 5 - 1 7 5 ~}$ (一-—), LM 25-125 (-- @--), LL 25-75 (---@---) 
Basal leaves were fully formed in GSI; thus, the $\mathrm{N}$ application rate used in GSII had no effect on basal leaf area (Table 4). However, at week 8 , there were significant linear and quadratic effects of GSII $\mathrm{N}$ rate on shoot dry weights and new leaf areas. Quadratic functions fitted to data from week 8 indicated that maximum responses of dry weight and new

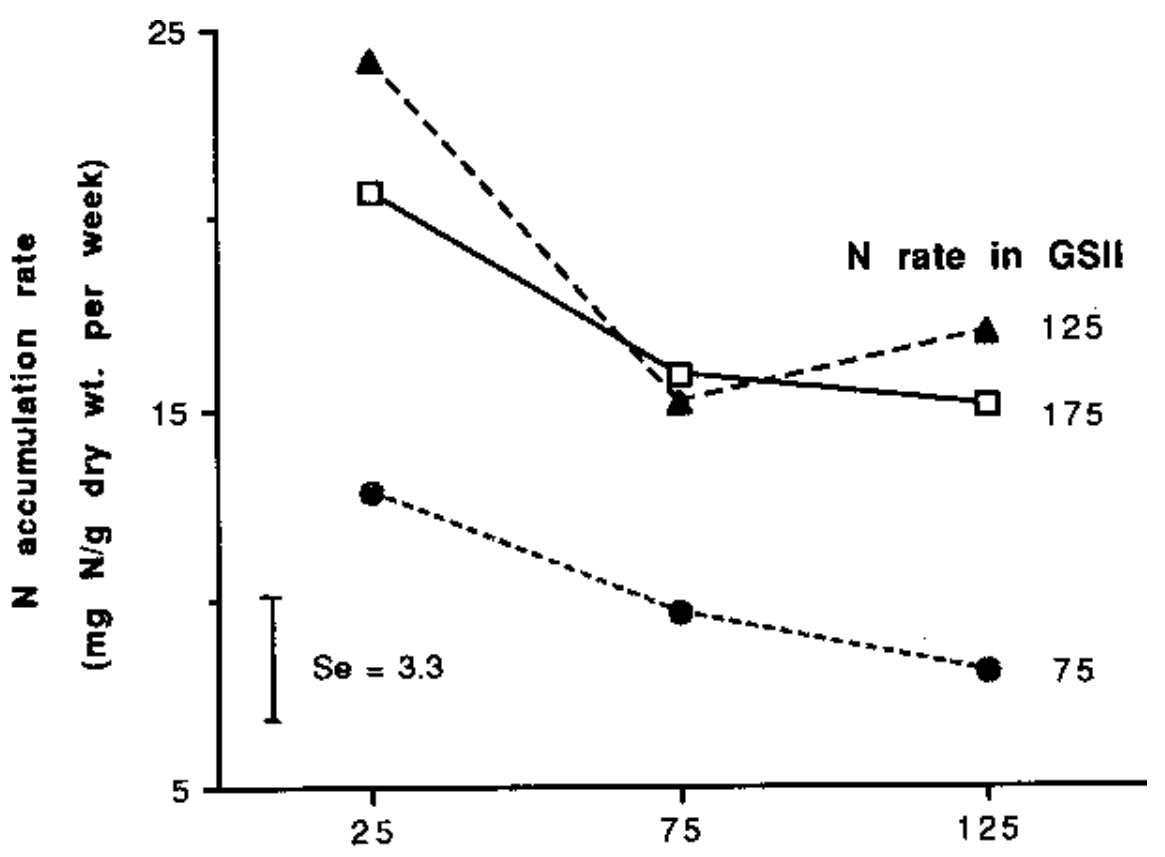

$\mathrm{N}$ rate in $\mathrm{GSI}$ ( $\mathrm{mg}$ N/iter)

Fig. 3. Average $\mathrm{N}$ accumulation rate per unit dry weight $\left(\mathrm{NAR}_{\mathrm{dw}}\right)$ for each treatment, weeks 7 through 8 . SE bar indicates SE of the difference between two main effect means.

Table 5. Effect of $\mathrm{N}$ rate on $\mathrm{NO}_{3}-\mathrm{N}$ concentration, electrical conductivity (EC), and $\mathrm{pH}$ of top, middle, and bottom layers of the container medium for week 4 and week 8 . Medium analyzed by saturated medium extract procedure.

\begin{tabular}{|c|c|c|c|c|c|c|c|c|c|}
\hline & \multicolumn{3}{|c|}{$\mathrm{NO}_{3}-\mathrm{N}\left(\mathrm{mg} \cdot \mathrm{liter}^{-1}\right)$} & \multicolumn{3}{|c|}{$\mathrm{EC}(\mathrm{mS})$} & \multicolumn{3}{|c|}{$\mathrm{pH}$} \\
\hline & \multicolumn{3}{|c|}{ Layer } & \multicolumn{3}{|c|}{ Layer } & \multicolumn{3}{|c|}{ Layer } \\
\hline & Top & Middle & Bottom & Top & Middle & Bottom & Top & Middle & Bottom \\
\hline \multicolumn{10}{|c|}{ Week 4} \\
\hline \multicolumn{10}{|l|}{ GSI N rate ${ }^{z}$} \\
\hline LO & 29 & 9 & 6 & 4.3 & 1.5 & 1.2 & 5.5 & 6.0 & 6.4 \\
\hline ME & 78 & 14 & 17 & 3.6 & 1.0 & 0.8 & 5.6 & 6.3 & 6.7 \\
\hline HI & 236 & 77 & 63 & 3.8 & 1.4 & 1.1 & 5.5 & 6.1 & 6.5 \\
\hline $\mathrm{N}$ & $\mathrm{L}^{* * *}$ & $\mathrm{~L}^{* * * *}, \mathrm{Q}^{*}$ & $\mathrm{~L}^{* * *}, \mathrm{Q}^{* *}$ & NS & $\mathrm{Q}^{*}$ & $\mathrm{Q}^{* *}$ & NS & NS & NS \\
\hline$r^{2}$ & 0.94 & 0.92 & 0.96 & 0.84 & 0.78 & 0.76 & 0.52 & 0.48 & 0.53 \\
\hline $\mathrm{SE}^{y}$ & 24 & 9.5 & 5.4 & 0.2 & 0.2 & 0.1 & 0.1 & 0.1 & 0.1 \\
\hline \multicolumn{10}{|c|}{ Week 8} \\
\hline GSI N rate ${ }^{z}$ & & & & & & & & & \\
\hline LO & 176 & 27 & 52 & 7.2 & 1.3 & 1.2 & 5.6 & 6.4 & 6.7 \\
\hline ME & 268 & 33 & 54 & 6.7 & 1.3 & 1.2 & 5.7 & 6.5 & 6.7 \\
\hline $\mathrm{HI}$ & 469 & 54 & 61 & 7.4 & 1.4 & 1.2 & 5.6 & 6.4 & 6.6 \\
\hline \multicolumn{10}{|l|}{ GSII N rate ${ }^{x}$} \\
\hline LO & 190 & 17 & 22 & 6.7 & 1.3 & 1.1 & 5.6 & 6.4 & 6.8 \\
\hline ME & 316 & 32 & 51 & 7.2 & 1.3 & 1.2 & 5.6 & 6.5 & 6.7 \\
\hline $\mathrm{HI}$ & 419 & 65 & 94 & 7.4 & 1.4 & 1.4 & 5.6 & 6.4 & 6.5 \\
\hline GSI & $\mathrm{L}^{* * *}$ & $\mathrm{~L}^{* *}$ & NS & NS & NS & NS & NS & NS & NS \\
\hline GSII & $\mathrm{L}^{* * *}$ & $\mathrm{~L}^{* * *}$ & $\mathrm{~L}^{* * * *}$ & NS & NS & NS & NS & NS & $\mathrm{L}^{* *}$ \\
\hline GSI $\times$ GSII & NS & NS & NS & NS & NS & NS & NS & NS & NS \\
\hline$r^{2}$ & 0.85 & 0.73 & 0.80 & 0.81 & 0.07 & 0.37 & 0.35 & 0.34 & 0.54 \\
\hline $\mathrm{SE}^{\mathrm{y}}$ & 34 & 7 & 7 & 0.3 & 0.2 & 0.1 & 0.1 & 0.1 & 0.1 \\
\hline
\end{tabular}

${ }^{2} \mathrm{GSI}=$ growth stage $\mathrm{I}$ with $\mathrm{N}$ rates (in $\mathrm{mg} \cdot \mathrm{liter}^{-1}$ ): $\mathrm{LO}=25, \mathrm{ME}=75$, and $\mathrm{HI}=125$.

${ }^{y_{S E}}$ of the difference between two treatment (week 4) or main effect (week 8) means.

${ }^{\mathrm{x}} \mathrm{GSII}=$ growth stage II with $\mathrm{N}$ rates $\left(\right.$ in $\left.\mathrm{mg} \cdot \mathrm{liter}^{-1}\right)$ : $\mathrm{LO}=75, \mathrm{ME}=125$, and $\mathrm{HI}=175$.

Ns, $, * * *, * * * *$ Nonsignificant or significant at $P \leq 0.05,0.01$, or 0.001 , respectively. $\mathrm{L}=$ linear, $\mathrm{Q}=$ quadratic.
GSI ( 25 to $125 \mathrm{mg}$ N/liter) had no significant effect on dry weight, their effect on shoot $\mathrm{N}$ concentration was linear (Table 2). Maust and Williamson (1994) also reported that the critical $\mathrm{N}$ application rate (where further increase in rate had no concomitant increase in a growth variable) was much lower for dry weight than tissue $\mathrm{N}$ concentration in citrus nursery plants. This result indicates that, at the lower $\mathrm{N}$ concentrations, tissue $\mathrm{N}$ concentration is a more sensitive indicator of $\mathrm{N}$ supply than dry weight. Increasing the $\mathrm{N}$ application rate in GSI also caused a corresponding increase in the average NAR of shoots per unit dry weight $\left(\mathrm{NAR}_{\mathrm{dw}}\right)$ from 6.1 (LO) to 13.8 (HI) $\mathrm{mg} \mathrm{N} / \mathrm{g}$ dry weight per week.

In GSII, after $\mathrm{N}$ application rates were increased by $50 \mathrm{mg} \mathrm{N} / \mathrm{liter}$, an inverse relationship developed between the $\mathrm{N}$ rate used in GSI, shoot $\mathrm{N}$ concentration, and $\mathrm{NAR}_{\mathrm{dw}}$. At week 6 , two weeks following the increase in rates, shoot $\mathrm{N}$ concentration was not significantly affected by any $\mathrm{N}$ rate used in GSI or GSII (Table 3 ), but by week 8 , the average shoot $\mathrm{N}$ concentration and the $\mathrm{NAR}_{\mathrm{dw}}$ (Fig. 3) of treatments receiving the LO rate in GSI $(25$ $\mathrm{mg} \mathrm{N} /$ liter) were significantly higher than for the other treatments (average $\mathrm{NAR}_{\mathrm{dw}}$ of plants receiving $\mathrm{LO}, \mathrm{ME}$, and $\mathrm{HI} \mathrm{N}$ rates in GSI = $19.2,13.5$, and $13.4 \mathrm{mg} \mathrm{N} / \mathrm{g}$ dry weight per week, respectively).

Nutrient-deprived plants may respond to nutrient availability by increasing their rate of nutrient uptake (Ingestad, 1974; Marschner, 1986). Evans and Cabrera (1993) observed that $\mathrm{N}$ uptake rates in roses (Rosa hybrida L.) increased 2 to 3 fold following 4-, 8-, and 16day N-deprivation treatments. In our experiment, the higher $\mathrm{NAR}_{\mathrm{dw}}$ values and shoot $\mathrm{N}$ concentrations in plants that received the LO $\mathrm{N}$ rate in GSI suggests that reversal of $\mathrm{N}$ deprivation after week 4 stimulated an increase in $\mathrm{N}$ uptake rate.

In contrast to our study, Tsutsui and Aoki (1981) reported that poinsettia shoot N concentrations remained constant when a higher range of $\mathrm{N}$ application rates was used (126 to $210 \mathrm{mg} \mathrm{N} /$ liter). In this range, shoot $\mathrm{N}$ concentration may be a relatively insensitive indicator of $\mathrm{N}$ supply. These authors speculated that poinsettias have a mechanism to maintain shoot $\mathrm{N}$ concentrations by restricting growth rate. Thus, it is possible that higher shoot $\mathrm{N}$ concentration and NAR $\mathrm{dw}_{\mathrm{dw}}$ observed in our GSI LO rate plants at week 8 may have resulted from lower dry weight accumulation rates, higher $\mathrm{N}$ uptake rates, or both.

Growing medium analysis, salt stratification. Salts accumulation at the growing medium surface typically occurs with subirrigation (Biernbaum, 1988). At all harvests (data shown from weeks 4 and 8 only), $\mathrm{NO}_{3}-\mathrm{N}$ concentrations and EC were high in the top layer of the growing medium (Table 5 ). By week 8 , the $\mathrm{NO}_{3}-\mathrm{N}$ concentration in the top layer (all treatments) was five to 10 times higher than in the middle and bottom layers, and few roots were observed in this layer. The middle and bottom layers of the medium had similar $\mathrm{NO}_{3}-\mathrm{N}$ concentrations and $\mathrm{EC}$, which suggests that roots exploited these layers 
equally. A gradient in $\mathrm{pH}$ was observed, increasing from the top to the bottom of the medium (Table 5).

Growing medium analysis, effect of $N$ ap plication. Nitrogen application rates had highly significant, mostly linear, effects on $\mathrm{NO}_{3}-\mathrm{N}$ concentration in the growing medium (Table 5). Throughout the experiment, acceptable growth and quality were noted in plants receiving any combination of $\mathrm{ME}$ and $\mathrm{HI}$ rates. Nonetheless, the $\mathrm{NO}_{3}-\mathrm{N}$ concentration in the growing medium of some of these treatments fell in the low range for the saturated extract procedure $(<40 \mathrm{mg} \mathrm{N} / \mathrm{liter}$, as defined by Warncke, 1988) (only middle and bottom layers are considered because removal of salt accumulation layers is recommended before testing). Optimal medium $\mathrm{NO}_{3}-\mathrm{N}$ levels (100 to $200 \mathrm{mg} \mathrm{N} /$ liter) were not achieved even in plants receiving $\mathrm{HI}$ rates in either growth stage (Table 5). Our findings indicate that poinsettias may be grown successfully at lower medium concentrations than indicated by the published standards.

Differences in EC were not consistent among $\mathrm{N}$ treatments (Table 5 ). This result was expected because all $\mathrm{N}$ treatment solutions had similar EC. Solutions with lower $\mathrm{NO}_{3}$ concentrations supplied correspondingly higher $\mathrm{Cl}$ concentrations because $\mathrm{CaCl}_{2}$ replaced $\mathrm{Ca}\left(\mathrm{NO}_{3}\right)_{2}$. In general, $\mathrm{N}$ application rate also had little effect on medium $\mathrm{pH}$ (Table 5).

\section{Discussion}

Although recommendations for growers commonly suggest fertilizing newly potted poinsettias both early and heavily, our results stress the importance of fertilizing poinsettias early but not heavily. Although most of the plants' leaf area and shoot dry weight developed in the inductive stage, lack of adequate $\mathrm{N}$ supply in the early vegetative stage had a profound impact on growth potential later in development and could not be compensated for by the highest rate used in the inductive stage. However, after $\mathrm{N}$ application rates were increased at week 5 , shoot $\mathrm{N}$ concentrations of $\mathrm{N}$-deficient, LO-rate plants increased rapidly. This increase demonstrated that, with the exception of senescent basal leaves, $\mathrm{N}$ applied in later growth stages could rapidly produce good foliage color regardless of the fertilizer rate used during early vegetative growth. This observation should not surprise growers who routinely manipulate $\mathrm{N}$ to produce attractive, dark-green foliage when finishing crops before sale.

Measurements of dry weight and new leaf area at final harvest indicated that growth was optimized when the HI rate was used in the early vegetative growth stage (GSI, $125 \mathrm{mg} \mathrm{N}$ / liter) and when the ME rate was used in the inductive stage (GSII, $125 \mathrm{mg} \mathrm{N} /$ liter) - the rates being identical in this case. However, acceptable plant quality was observed in treatments receiving any combination of $\mathrm{ME}$ and $\mathrm{HI}$ rates in the two growth stages. This finding suggests that in the early vegetative stage, 75 to $125 \mathrm{mg} \mathrm{N} /$ liter is an acceptable range for poinsettia fertilization when subirrigation is used. Although the lower end of this range may cause some restriction in growth, it is an environmentally sound choice due to 1) the need for growth regulators may be reduced and 2) $\approx 20 \%$ less $\mathrm{N}$ was applied to the $\mathrm{ME}-$ ME than the HI-ME rate combination. Furthermore, heavy fertilization has been linked to inferior postharvest quality and longevity in potted chrysanthemums (Carver and Tayama, 1992). It would be worth investigating whether moderately restricting growth in the early vegetative stage by limiting $\mathrm{N}$ improves quality and reduces stem breakage, a serious postharvest problem in poinsettias.

A plant's maximum potential for uptake and use of nutrients depends on irradiance, temperature, water availability, and other environmental factors. In this experiment, the growth room environment was much more stable than a greenhouse would be. However, the mean daily temperatures in the growth room were within 1 to $2 \mathrm{C}$ of mean temperatures that fall-grown poinsettia crops experienced in the The Pennsylvania State Univ.'s greenhouses (first 8 weeks of growth, 1991 and 1992). Daily light integrals in the growth room exceeded those in the greenhouse. These relationships suggests that $\mathrm{N}$ sufficiency ranges observed in our experiment also may be adequate for greenhouse-grown, subirrigated poinsettia crops.

\section{Literature Cited}

Argo, W.R. and J.A. Biernbaum. 1991. The effect of fertilizer, nutrient charge, and irrigation method on early vegetative and root growth of poinsettia 'V-14 Glory'. HortScience 26:763. (Abstr.)

Biernbaum, J.A., R.G. George, R.D. Heins, and W.H. Carlson. 1988. Subirrigation with recirculating solutions. Grower Talks 52(9):79-84.

Bremner, J.M. 1965. Total nitrogen, p. 1149-1178. In: C.A. Black (ed.). Methods of soil analysis, Part 2. Amer. Soc. Agron., Madison, Wis.

Carver, S.A. and H.K. Tayama. 1992. Production fertilizer levels influence post-production flower keeping quality. Ohio Florists' Assn. Bul. 756:3-6.

Ecke, P., Jr., O.A. Matkin, and D.E. Hartley. 1990 The poinsettia manual. 3rd ed. Paul Ecke Poinsettias, Encinitas, Calif.

Evans, R.Y. and R.I. Cabrera. 1993. Reducing N leaching losses in greenhouse roses: Effect of periodic $\mathrm{N}$ fertilization on $\mathrm{N}$ uptake and flower yields. Roses Inc. Bul. June:61-66

Hunt, R. 1990. Basic growth analysis: Plant analysis for beginners. Unwin Hyman, London.

Ingestad, T. 1974. Towards optimum fertilization. Ambio 3(2):49-54.

King, J. and D. Stimart. 1990. Quantities and forms of $\mathrm{N}$ uptake throughout development in chrysanthemum. HortScience 25:170. (Abstr.)

Klemm, K. 1966. Der Einfluss der N-form auf die Ertragsbildung verschiedener Kulturpflanzen. Bodenkultur 17:265-284.

Marschner, H. 1986. Mineral nutrition in higher plants. Academic, London.

Maust, B.E. and J.G. Williamson. 1994. Nitrogen nutrition of containerized citrus nursery plants. J. Amer. Soc. Hort. Sci. 119:195-201.

Nell, T.A. and J.E. Barrett. 1986. Growth and incidence of bract necrosis in 'Gutbier V-14 Glory' poinsettias. J. Amer. Soc. Hort. Sci. 111:266-269.

Senecal, M., B. Dansereau, and R. Paquin. 1989. Fertilization and night temperature affects growth and carbohydrate status of poinsettia. Can. J. Plant Sci. 69:347-349.

Tolman, D.A., A.X. Niemiera, and R.D. Wright. 1990. Influence of plant age on nutrient absorption of marigold seedlings. HortScience 25:1612-1613.

Tsutsui, K. and M. Aoki. 1981. Response of poinsettias to major nutrient supply in relation to nutrient uptake and growth. Bul. Veg. Ornamental Crops Res. Sta. Ano Jpn. Ser. A. 8:171-207.

Warncke, D. 1988. Recommended test procedure for greenhouse growth media, p. 34-37. In: W.C. Dahnke (ed.). Recommended chemical soil test procedures for the north central region. North Central Regional Publ. 221 (revised). 